\title{
MULTIPARADIGMATIKUS MEGKÖZELÍTÉS VÁLASZA A PARADIGMAVITÁRA
}

A cikk azt az elméleti kérdést vizsgálja, hogy a szervezetelméletek területén definiált paradigmák milyen viszonyban állnak egymással, és a szakirodalomban elterjedt összeegyeztethetôségi vitának milyen perspektívái léteznek. A szerzố szerint erre a vitára leginkább a multiparadigmatikus megközelítés ad választ. Ugyanakkor kiemeli a szerzố, hogy a multiparadigmatikus megközelítés nem tagadja az összeegyeztethetôségi vitát, nem integrálja vagy keveri a paradigmákat. A multiparadigmatikus megközelítésnek több fajtáját mutatja be a cikk: a zárójelbe tételt, a zárójelbe tételt és hídverést, a hídverést, a párhuzamos és szekvenciális kutatást, metaelmélet-építést és az interplayt.

\section{Kulcsszavak: szervezetelméletek, paradigmák, kutatásmódszertan}

Mindannyian rendelkezünk valamilyen zenei ízléssel. Van, aki a klasszikus zenét kedveli, mások a rockot, megint mások a jazzt vagy éppen a népzenét. Sokszor egyes zenei irányzat kedvelói hallgatni sem bírják a másik zenei irányzat múveit. Ugyanakkor vannak olyan emberek, akik többféle zenei irányzatot kedvelnek. Legtöbben közülük azt mégsem tudják elképzelni, hogy ezeket az egymástól nagyon különböző zenéket valaki összekeverje. A legtöbb keverék egyébként meglehetôsen falsul hangzana. Azonban ha valaki kelló arányérzékkel elegyíti egymással a fent említett stílusokat, zenei irányzatokat, hihetetlen élményhez vezethet. Ilyen zenét játszik például Magyarországon a Free Style Chamber Orchestra (FSCO): meglepően elkülönülnek a zenészek nemcsak hangzásban, de már megjelenésben is, mégis az összhatás olyan eredeti, hogy nehéz megkérdójelezni a felállás létjogosultságát.

Hasonló a helyzet a szervezetelméletekkel, számtalan létezik, amelyek mindegyike a szervezetek létét, múködését írja le, magyarázza, tárja fel. Miért van ennyi szervezetelmélet? Mindegyik igaz? Mindegyik egyformán hozzásegít a szervezetek megértéséhez? Mindegyik szervezetelméletet ismerni kell, hogy egy szervezetet kutassunk? Nincsenek ellentmondások az elméletek között? Ha vannak ellentmondások, akkor mi alapján választhatunk, hogy melyik elmélet jó, és melyik rossz? Ezeket a kérdéseket fogom körbejárni ebben a tanulmányban: röviden áttekintem a szervezetelméletek paradigmáit, hogy a legnagyobb vita - a paradigmavita - lényegét bemutassam, és ha már világos, hogy miról és miért vitatkoznak a szervezetelméletek, adok rá egy választ: a multiparadigmatikus megközelítést. Nem mindenki fogadja el ezt, mint a vitára adott jó választ. Sokan „nem válasznak” vagy kitérésnek tekintik ezt. Remélem sikerül óket is meggyőznöm, hogy én miért tartom ezt egy lehetséges és egyben a leghitelesebb megoldásnak, és nem „hangzik falsul a végeredmény".

\section{Milyen paradigmák léteznek a szervezetelméletek területén?}

Amióta Kuhn kifejtette tudománytörténeti (az ô esetében fizikatörténeti) vizsgálódásait, úgy túnik, hogy a tudományos gondolkodásunk paradigmákra épül. Sokszor úgy látjuk, hogy szinte nem létezik kommunikáció paradigmák között, viszont paradigmákon belül virágzó kommunikáció és kutatás zajlik. Ezért tudományról átfogó képet adó szerzók gyakran paradigmák köré rendezik a mondandójukat. Mit is jelent a paradigma? 
Kuhn (2002) után szabadon (1) tudományos közösséget (180-186. old.), (2) közös megkérdójelezhetetlen alapfeltevéseket (186-192. old.), (3) közös példákat (192-195. old.), (4) tacit tudást és intuíciót (196-202. old.). Azaz a paradigmák köré tudományos közösségek szerveződnek, amelyek olyan közös alapfeltevésekkel élnek a kutatásaikban, amelyeket eszükbe sem jut megkérdőjelezni, hasonló empirikus eredményekre jutnak (amely egyébkent megerósíti a paradigmába vetett hitüket), és kialakul egy olyan tacit tudás, amelyet elmondani, megosztani nem tudnak, hasonló intuícióik vannak, egy paradigmát követő kutatók olyan gondolati összhangban vannak, hogy szinte félszavakból megértik egymást. Kuhn (2002) jelentős teret szentel a paradigmák összemérhetetlenségének. (Magyarul öszszeegyeztethetetlenségnek és összemérhetetlenségnek is szoktuk fordítani az inkommenzurabilitást.) Kuhn (2002) szerint a paradigmák között nincs érdemi kommunikáció, mert a különböző paradigmák kijelentései értelmetlenek a másik paradigmában.

Különösen ez utóbbi miatt az egymással kommunikálni nem képes iskolákat a tudományos életben gyakran paradigmáknak hívjuk. Levie (1993) mechanikai, organizmikus és evolúciós paradigmákról beszél a Vezetéstudományban megjelent cikkében, amelyek szerinte meghatározóak a szakterületünkön. Ebból a mechanikai és organizmikus egymással kibékíthetetlen, viszont a korai menedzsmenttanok között is felfedezhetốk és a stratégiai menedzsmentben is megtalálhatók, az evolúciós paradigma viszont e kettő összebékítése és szintézise.

Hatch (1997) a szervezetelméletekben három perspektíváról ír: (1) modern, (2) szimbolikus és (3) posztmodern; amelyek a leírás alapján paradigmának tekinthetốk. Hatch (2006) második kiadásában ezt kiegészíti a kritikai iskolával, amely megfogalmazása szerint „mainstream”-é vált mára. Primecz (1999) cikkében a pozitivizmusról, kritikai realizmusról és posztmodernizmusról beszél, mint a szervezetekról való gondolkodás alapmegközelítéséról. Hatch és Cunliffe (2006) második kiadványában szintén megjelenik a kritikai realizmus, mint új irányzat a szervezetelméletekben a modern és a szimbolikus megközelítés között. (Ontológiai szempontból a kritikai realizmus modernnek számít, episztemológiai szempontból viszont szimbolikusnak.) Ugyanakkor más új irányzatokat is felsorol Hatch (2006): a komplexitáselméletet, a networkelméletet, a szervezeti identitást, a szervezeti esztétikát. Nem egyértelmú, hogy mit tekinthetünk külön paradigmának, mit csak iskolának.

Tsoukas és Knudsen (2003) szervezetelméleti szöveggyújteménye négy nagy iskolából indul ki, amelye- ket egyértelmúen tekinthetünk paradigmáknak: (1) pozitív tudomány (Donaldson), (2) interpretív tudomány (Yanow, Hatch), (3) kritikai tudomány (Willmott) és (4) posztmodern tudomány (Chia). A négy jól elkülönülő irányzat paradigmaként múködik: iskolát teremt, alapfeltevéseiben összefüggő rendszert alkot, empirikus eredményei összhangban vannak egymással, létezik egy tacit tudás és intuíció a közösségben, és nem utolsósorban, a tényleges kommunikáció elenyésző, ha egyáltalán van köztük.

Mégis, amikor a szervezetelméletek területén paradigmavitáról, összeegyeztethetetlenségról, multiparadigmikus megközelítésról beszélünk, Burrell és Morgan által 1979-ben meghatározott négy paradigmára gondolunk: (1) funkcionalista, (2) interpretív, (3) radikális humanista és (4) radikális strukturalista. Miért jobb ez a felosztás más felosztásnál? Mert Burrell és Morgan talált két olyan alapvető kérdést, amelyekre adott válaszok meróben megosztják a társadalomtudományok területén kutatókat, és mivel a két kérdés független egymástól, ezek alapján egy kétszer kettes mátrixot lehet létrehozni, és a négy negyed négy különbözó paradigmát határoz meg. Burrell és Morgan mátrixát magyarul elóször Bokor (1994) ismertette röviden, majd Gelei (2002) részletesebben, továbbá a Vezetéstudomány hasábjain Gelei (2006) tollából olvashattunk egy leírást is.

Burrell és Morgan (1979) abból indult ki, hogy a szervezetelemzés (ma már inkább szervezetelméleteket mondanánk) ugyanazon töréspontok mentén oszlik meg, mint a társadalomtudományok, konkrétabban a szociológia: (1) a társadalomtudományok alapvetôen objektívek vagy szubjektívek, illetve (2) a társadalmi berendezkedést vagy elfogadjuk, vagy elvetjük. Ezek a kérdések - még ha explicit módon nem is mindig jelennek meg - alapvetốn elválasztják egymástól az elméleteket. Burrell és Morgan (1979) szerint minden kutatónak van explicit vagy implicit válasza erre a két kérdésre, azaz minden kutató (és kutatás) ezáltal besorolható valamelyik síknegyedbe. Gelei (2006) részletesen leírta az objektív-szubjektív tengelyt, és említést tett a társadalmi rend és radikális változás tengelyról, emellett kiemelnék néhány további sarokpontot is.

Az objektív-szubjektív tengely nem egyszerúen a hétköznapi életben használatos dichotómia, hanem eltérő tudományfilozófiát (1) ontológiát (lételmélet), (2) episztemológiát (tudományelmélet), (3) emberképet és (4) metodológiát takar. Sokszor félreértett kérdés: az objektív tudományfilozófia is ismeri a szubjektivitást, de ennek kiküszöbölésére törekszik, azt hibának tekinti vagy legalábbis minimálisra csökkentendőnek. A szubjektív tudományfilozófia viszont azt állítja, hogy 
az objektivitásra törekvés csak leplezi a szubjektivitást, mert a valóság nem rajtunk kívül, hanem (döntô részben) bennünk létezik (legalábbis a társas/társadalmi) valóság, ezt mi konstruáljuk cselekedeteinkkel és kommunikációnkkal. Másik sokszor félreértett különbség, hogy bár a szubjektív tudományfilozófia az egyénre épít, de annak a közösségi, kollektív, közösen kialakított konstruált voltára, azaz az egyéni/egyedi vezet el a közöshöz. (Az egyéni eltérések nem lényegesek, amíg a közösség arra nem reflektál, és be nem épül a társas konstrukcióba.)

A másik tengely (rend szociológiája és változtatás szociológiája) is mélyebb törésvonal, mint a hétköznapi értelemben vett rend és változás. A változtatás szociológiája alatt azt értjük, hogy a fennálló társadalmi rendet (kapitalista fogyasztói társadalmat) kívánja megváltoztatni egy emberközelibb társadalomra, így a fennálló hatalmi struktúrákat elvetné. A fennálló hatalmi elit részei például a mai szervezetek tulajdonosai, menedzserei, vezetői, de ugyanígy a felsőoktatás, és mindaz, ami újratermeli a fennálló társadalmi rendet, és ideológiát nyújt ennek újratermeléséhez (pl. gazdasági felsőoktatás). A rend szociológiája pedig amellett érvel, hogy - ha vannak is hibái a kapitalista fogyasztói társadalomnak - a jelenlegi társadalmi rend a legjobb. A rend szociológiája sem zárja ki (még a társadalmi) változást sem, azonban ez inkább apróbb; lényegi társadalmi és hatalmi viszonyokat nem érint.

A funkcionalista paradigma az objektivista tudományfilozófiára és a rend szociológiájára épít. Szociológiai gyökerei a következô szociológusok munkáiból táplálkozik: Comte, Spencer, Pareto, Durkheim, Weber (bár ô az élete során váltott paradigmát), Simmel, Mead. A konkrét szervezetelméleti iskolák, amelyeket Burrell és Morgan (1979: 30. old.) említ: objektivizmus, társadalmi rendszerelmélet, a bürokrácia diszfunkciójának elméletei, pluralizmus, 'action frame of reference'. Bár az eredeti publikációban ezek az elméletek szerepelnek, ezt érdemes kiegészíteni Bácsi - Primecz (2006) alapján, vagy a szervezetelméletek tárgyban oktatott kontingenciaelmélettel, rendszerelmélettel, intézményi közgazdasági elmélettel, populációs ökológiával. Eszerint a megközelítés szerint a Levie (1993) által említett mechanikai, organizmikus és evolúciós paradigmák inkább iskoláknak számítanak, és mind a funkcionalista paradigmába tartoznak. A Hatch (1997), Hatch - Cunliffe (2006) által említett modern megközelítés gyakorlatilag megegyezik a funkcionalista paradigmával. Donaldson (2003) pozitív tudományról szóló tanulmánya Tsoukas szöveggyújteményében gyakorlatilag a Burrell - Morgan (1979) -féle funkcionalista paradigmát jellemzi.
Az interpretív ${ }^{1}$ paradigma szubjektív tudományfilozófiára és a rend szociológiájára épít. Burrell és Morgan (1979: 31. old.) a paradigma előfutárai között Kantot, Dilthey-t, Webert (paradigmát váltott), Husserlt, Schutzot említik, szociológiai iskoláként hermeneutikát, fenomenológiát és részben a szolipszizmust nevezik meg. Szervezetelméleti iskolaként az etnometodológiát és a fenomenológiai szimbolikus interakcionalizmust. Az 1979-es eredeti publikációt ma már ki lehet egészíteni további iskolákkal, erról részletesen ld. Gelei (2006), illetve néhány adalék Bácsi - Primecz (2006). Tsoukas (2003) szöveggyújteményében a Yanow - Hatch (2003) cikk egyértelmúen ezt a paradigmát írja le részletesen. Hatch (1997), Hatch - Cunliffe (2006) szervezetelméleti könyvében lényegében a szimbolikus megközelítés megegyezik az interpretív paradigmával. Érdekes, hogy Hatch - Cunliffe (2006) a szervezeti esztétikát külön új irányzatként mutatja be, holott alapfeltevéseiben megegyezik az interpretív (vagy ahogy ô hívja szimbolikus) paradigmával, ez ennek inkább egy iskolája. Az intézményi szociológia egy olyan iskola, amelynek megítélése változó, hogy mely paradigmába tartozik. Hatch - Cunliffe (2006) a szimbolikus (azaz interpretív) paradigmába sorolja, míg szervezetelméletek oktatása során oktató csapatunk a funkcionalista elméletek között szokta oktatni, de úgy, mint egy lépés az interpretív paradigma felé.

A radikális strukturalista paradigma objektivista tudományfilozófiára és társadalmi változtatásra épít, azaz megkérdôjelezi a kapitalista társadalom létjogosultságát. Nem véletlen, hogy a gyökereit olyan társadalomtudósokban definiálja, mint például (az érett) Marx, Engels, Plehanov, Lenin és Buharin. Burrell és Morgan említi még Weber egyes múveit, amelyek komoly társadalomkritikát fejtettek ki; nyugati szociológusok közül pedig Dahrendorf az egyik legjelentôsebb forrás. A társadalomelméletek közül - az elóbbiek alapján már nem meglepó - az orosz társadalomelméletek, a konfliktuselmélet és a jelenkori mediterrán marxizmus a fó iskolák. A szervezetelméletek területéről röviden és összefoglalóan a radikális szervezetelméleteket nevezi meg a szerzőpáros. Burrell és Morgan (1979) eredeti forrásának születésekor ez a paradigma a szervezetelméletek területén szinte csak elméletileg létezett. Ma komoly kritikaimenedzsment-iskola van, amelynek létezik radikális strukturalista irányzata is, bár kétségtelen, hogy a rend szociológiájához tartozó két paradigma (különösen a funkcionalista paradigma) messze erősebb, mint a kritikai iskolák (radikális strukturalista, radikális humanista). Ld. erról részletsebben Gioia és Pitré (1990). 
Végül a radikális humanista paradigma, amely szubjektivista tudományfilozófiát feltételez, és társadalmi változások igényével lép fel. A társadalomelméleti gyökereit az alábbi tudósokban definiálja: Kant, Hegel, (az ifjú) Marx, Husserl, Lukács, Gramsci, Habermas és Marcuse, említi még Sartre-ot és Laing-et. A társadalomelméletek közül a szolipszizmust, a francia egzisztencializmust, az anarchista individualizmust és a kritikai elméleteket említi a szerzôpáros. Valószínúleg ez a másik olyan területe a szervezetelméleteknek (és ezzel együtt a társadalomelméleti alapoknak), amely sokat változott az elmúlt évtizedekben. Burrell és Morgan (1979) egyszerúen csak anti-szervezetelméletnek hívja a radikális humanizmusba eső szervezetelméleteket. Mára a kritikaimenedzsment-iskola a radikális humanista paradigmát tartja a fố bázisának (Willmott, 2003).

Burrell és Morgan 1979-es publikációjában nem foglalkozott a posztmodern paradigmával, azonban késóbb annál többet. Felmerül a kérdés, hogy ha ennyire lényeges kérdések köré rendezte Burrell és Morgan a paradigmákat, mi a posztmodern paradigmának a válasza a két meghatározó kérdésre, és ezáltal hol van a mátrixban. Bokor (1994) úgy fogalmaz, hogy az interpretív és radikális humanista paradigma felett lebeg. Ez így részben igaz, hiszen a szubjektivista tudományfilozófia mellett tör lándzsát, és valóban vannak irányzatai, amelyek inkább megértésorientáltak (tehát az interpretív paradigmához állnak közel), és vannak irányzatai, amelyben kritikai gondolatok is vannak a szó társadalomelméleti értelmében (tehát radikális humanista). Olyan szempontból is elképzelhetô, hogy a posztmodern egyik fố tézise a kibékíthetetlen ellentétek (jelen esetben társadalomelméletek) együttélése. Ugyanakkor a posztmodern per definitionem elvet minden nagy narratívát (Lyotard, 1993), és mi más a Burrell - Morgan (1979) mátrix, ha nem egy nagy narratíva. (Késóbb ebben a tanulmányban Chia [1996] érveivel olvasható ennek egyik oka.) Ugyanakkor nem árt megjegyezni, hogy a 90-es évek szakirodalmában a multiparadigmatikus ${ }^{2}$ megközelítés (amely természetesen elfogadja a Burrell - Morgan mátrixot) tipikus posztmodern megközelítésnek számított, ld. pl. Schultz és Hatch (1996).

\section{Összeegyeztethetetlenségi vita}

Az összeegyeztethetetlenségi vita fel sem merülne, ha a paradigmák békésen egymás mellett léteznének, és a paradigmák képviselői nem akarnák azt megmutatni, hogy az ô paradigmájuk miért jobb, mint valamelyik másik. A vita (idegen szóval inkommenzurabilitási vita) lényege az, hogy a különbözó paradigmák talaján álló (és kutató) kutatók között létezik-e érdemi kommunikáció, tudnak-e ók egymással beszélgetni, megérthetik-e egymást, esetleg elképzelhető-e köztük együttmúködés, közös kutatás, vagy ezeken túl együtt jobban megérthetik-e a szervezeti valóságot. A 90-es években ez a kérdés több meghatározó kutatót állásfoglalásra sarkallt, ezeket fogjuk most áttekinteni. Az elsố jelentős csoportosítás, amely a témában született, Scherertől származik (Scherer, 1998; Scherer - Steinmann, 1999; Scherer, 1999, magyar fordítása: 2002). Scherer csoportosítása nagy vitát váltott ki, amelynek eredményeit az Organization c. szaklap 1998-as összeegyeztethetetlenségi különszámában olvashatjuk. Késóbb Hassard és Kelemen (2002) gyưjiötték össze az álláspontokat, a cikk jelenleg a témában a legjobb összefoglaló. A vita, úgy túnik, csillapodik, kialakultak az álláspontok, megszülettek a válaszok pro és kontra a kérdésekben, további közeledés, távolodás, összecsapás nem várható.

$\mathrm{Az}$ összeegyeztethetetlenségi vita perspektívái Scherer szerint: (1) ,izolacionizmus”, (2) „viszsza az alapokhoz”, (3) „anything goes” és a (4) „multiparadigmikus perspektíva”. Az összeegyeztethetetlenségi vita - a Burrell - Morgan mátrixot alapul véve - azt feltételezi, hogy az egymás mellett élő paradigmák mindegyike megalapozott, konzisztens, nem hibás; csak éppen ellentétes, sốt komplementer (egymást kizáró) alapfeltevéseket fogadnak el, és erre építik fel az elméleteiket.

Scherer $(1998,1999)$ az izolacionizmust úgy írja le, amely szerint nem szabad megdönteni a paradigmák pluralizmusát, hangsúlyozza, hogy az egymásnak alapfeltevéseiben ellentmondó paradigmák között nem létezik racionális (sic!) választás. Az álláspont képviselôi szerint paradigmán belül kell konzekvensnek és megalapozottnak maradni, más kritérium nincs. Scherer az izolacionalizmus leírásakor elsôsorban Burrell és Morgan (1979) eredeti publikációjára és Jackson és Carter (1991, 1993) paradigmavitában kifejtett álláspontjára támaszkodik. Mind a négy szerzố az idézett múvekben amellett érvel, hogy mivel a paradigmák alapfeltevései kölcsönösen kizáróak, nem lehet öszszeegyeztetni a paradigmákat. Scherer (1998, 1999) továbbmegy - Kuhnra építve -, szerinte értelmes kommunikáció sem létezik a paradigmák között, és nem is kellene megpróbálni. Burrell és Morgan (1979) kétségtelenül minden lehetséges fórumon a paradigmák diverzitása mellett foglaltak állást, de valószínúleg sokkal inkább azért, mert bármilyen összeegyeztetés eredményeképp létrejött eredmény a mainstream (funkcionalista) paradigma erősödését vonná maga után, ami - ahogy Scherer (1999) fogalmaz - egy pa- 
radigma indokolatlan dominanciájához vezetne. Azonban vegyük észre, míg Burrell és Morgan a paradigmák pluralizmusa mellett érvelnek, hoznak arra is példát, hogy akár egy konkrét kutató átélhet paradigmaváltást (a fiatal és érett Marx munkáit hozzák példának [25. old.], késóbb más kutatók pl. Max Weber kapcsán is hasonlókat állítanak), elismerik, hogy ez ritka, de lehetséges, ami azt bizonyítja, hogy a paradigmák között nem teljesen kizárt a kommunikáció. Burrell és Morgan (1979) szerint,viszont - ahogy fogalmaznak - az „interparadigmikus utazások” nagyon ritkák.

Scherer $(1998,1999)$ a „vissza az alapokhoz” elnevezést használja az integrációs megközelítésre, amelyet Reedtól (1992) származtat, viszont az irányzat legjelentôsebb képviselóje, Donaldson (1998) kifejti, hogy ezt nem így, hanem más irodalomban (pl. a saját cikkeit is idézi) megszokott integrációnak kellene hívni. (Scherer egyébként a Steinmannal közös cikkében így is nevezi.) Tartalmi kérdésekkel folytatva az irányzat képviselôi amellett érvelnek, hogy a paradigmák pluralizmusát meg lehet, vagy meg kellene szüntetni. Donaldson (1998) ilyen szempontból a megengedóbb: szerinte empirikus tesztekkel el lehet dönteni, hogy az adott paradigma megállja-e a helyét, vagy nem. Itt persze nem fogadja el Burrell és Morgan (1979) azon alapfeltevését, hogy minden empirikus vizsgálat mögött olyan alapfeltevések állnak, amelyek meghatározzák a kutató paradigmáját, azaz empirikus tesztekkel nem lehet eldönteni, hogy melyik paradigma a jobb, hiszen bármelyik paradigma igazolná magát a saját empirikus vizsgálatában. Donaldson (1998) ezzel együtt nem lép fel olyan határozottsággal a paradigmák pluralizmusa ellen, mint Pfeffer (1993), aki szerint kontrollált dogmatizmusra lenne szükség, mivel a tudományterületünk kárát látja a paradigmikus egyet nem értésnek, szerinte gyengíti a szervezetkutatást a paradigmák diverzitása, és komolytalanná teszi a tudományterületünket. Pfeffer (1993) politikai eszközöket javasol, pl. ha a kiadók, lapok, konferenciák tudatosan egyetlen paradigmát támogatnának, akkor kialakulhatna egy erós paradigma. Pfeffer (1993) egyébként - a pragmatikus célokat leszámítva, pl. finanszírozási lehetóségek, tudománypolitikai elfogadottság - arra a tudományfilozófiai érvre épít, hogy Kuhn (2002) szerint a tudomány preparadigmatikus állapotában több egymás mellett élố paradigma volt, és ezt követték az egy domináns paradigmára épülő normál tudományos időszakok. Pfeffer (1993) szerint fiatal tudományterületünk érettebb korszakba lépne, ha nem több paradigma élne egymás mellett.

A fenti két megközelítés kibékíthetetlen ellentéte mellé Scherer (1998, 1999) Feyerabend (2002) „,anything goes” álláspontját teszi, amely szerinte szél- sőségesen relativista, és Scherer úgy fogalmaz, hogy e megközelítés szerint minden tudományos és gyakorlati álláspont egyenlő. Ezzel szemben a feyerabendi (2002) megközelítés inkább tekinthető szélsőségesen realistának, mint relativistának, hiszen Feyerabend semmilyen elớró állítást nem tesz könyvében, hanem részletesen megvizsgálja, hogy a tudósok hogyan kutattak a múltban. Arra a következtetésre jut, hogy nem lehet semmilyen konzekvens szabályt találni arra nézve, hogy mely kutatást tekintették tudományosnak és melyiket nem, és erre született a szállóigévé vált, eredetileg ironikus megjegyzése: bármi megteszi (anything goes). Valószínúleg lehetne a szervezetkutatásban is egy ilyen vizsgálatot végezni, hogy miként kutatnak a kutatók, és valószínúleg hasonló eredmények jönnének ki: nincs egységes kritérium, amely szerint meg lehet ítélni, hogy mi tudományos és mi nem. Scherer (1999) úgy túnik, mint egyébként nagyon sokan, félreérti Feyerabendet, és veszélyként fogja fel annak nagyon alapos kutatáselméleti elemzését, és Scherert (1999), Schreyögöt (1992) is idézi, hogy ez a tudomány ellehetetlenüléséhez is vezet. Ezzel szemben ez még nem vezet ehhez, mivel Feyerabend elốtt sem lehetetlenült el a tudomány, attól pedig nem fog, hogy Feyerabend rámutatott, hogy a tudományosság kritériuma nem egységes, korszakonként és iskolánként változó. Mindemellett úgy túnik, maguk a kutatók nem hagyják, hogy kívülról valamilyen egységes kritériumot határozzon meg valaki, mert ez a kutatói szabadságukat veszélyeztetné. (Ugyanakkor - erre Feyerabend is rámutatott - minden korban kialakul a tudományosság valamilyen kritériumrendszere, de leginkább organikus, a kutatók többsége által elfogadott módon.)

Scherer (1999) negyedikként bemutatott megközelítése a multiparadigmatikus perspektíva, amelyból Scherer (1999) azt emeli ki, hogy a versengó paradigmákról folytatott párbeszéd az alapja a tudományos előrelépéseknek. Azt is hozzáteszi Scherer (1999), hogy a multiparadigmatikus megközelítés majdnem minden követője elismeri az összeegyeztethetetlenségi tézist, de a kutató kutatása tárgyát több paradigma szemszögéból vizsgálja. (Többek között Gioia és Pitré (1990), Hassard (1991) és Schultz és Hatch (1996) tanulmányait idézi.) Scherer $(1998,1999)$ és Scherer és Steinmann (1999) valószínúleg kihagyták azt az alapfeltevést, hogy a multiparadigmatikus nézópont azt feltételezi, hogy minden paradigma helyes, és ha konzekvensen alkalmazzák, akkor helyes eredményekhez is vezet, bár minden paradigma (az alapfeltevései különbözőségénél fogva) mást érzékel valóságként, de egymással nem ellentmondóak ezek a valóságképek. Ezeknek az alapfeltevéseknek az elfogadása mellett teljesen 
értelmetlenekké válnak azok az állítások, amelyeket Scherer $(1998,1999)$ és Scherer és Steinmann (1999) a multiparadigmatikus megközelítés ellen állított, azaz „bármelyik perspektíva hibás lehet, a kombinációjuk még rosszabb" (Scherer - Steinmann, 1999: 523. old.). Itt derül ki, hogy Scherer szerint valamelyik paradigma alapfeltevései hibásak lehetnek. Aki ezzel az alapfeltevéssel él, valóban nem folytathat multiparadigmatikus kutatást. Így az általa javasolt megoldás (radikális konstruktivizmus, erlangeni iskola) az összeegyeztethetetlenségi vitában is elvethetô ennek ismeretében, hiszen nem tartja mindegyik paradigmát helyesnek, azaz a javasolt módon egy paradigmához jutunk el, nem oldja meg a paradigmavitát.

Scherer (1998, 1999) és Scherer és Steinmann (1999) tipológiája nagyon sok kritikát kapott, de kétségtelenül elômozdította azt a folyamatot, amelynek végén Hassard és Kelemen (2002) cikke megszületett. A szerzőpárosról tudni kell, hogy Hassard az elsók közé tartozott, akik tudatosan és konzekvensen végigvittek egy multiparadigmatikus kutatást (késóbb részletesebben bemutatom), és Kelemen a multiparadigmatikus kutatások tipológiájáról publikált (többek között).

Hassard és Kelemen (2002) másképp közelítik meg a problémát: a szervezeti tudás „termelését” és „fogyasztását" vizsgálják. Szerintük a paradigmák öszszeegyeztetéséról szóló vita után a tudás termelése és fogyasztása alapján öt táborba (camp) sorolhatók a kutatók. A táborok különbözô választ adnak a tudományosság kritériumaira és az intézményi kontrollra. Ezek a táborok a következők: (1) nemfogyasztók, (2) integracionisták, (3) protekcionalisták, (4) pluralisták és (5) posztmodernek. Szerintük mindegyik tábor alapfeltevéseit cáfolni lehet, és a paradigmákat diskurzusokkal kellene lecserélni. Az egyes táborok az alábbiak szerint foglalhatók össze:

A „nemfogyasztók” tábora Hassard és Kelemen (2002) szerint nagy, és talán nem túlzás azt mondani, hogy a kutatók nagy része ide tartozik. Ók nem követik nyomon a paradigmák alapfeltevéseit, elterjedésüket, az összeegyeztethetetlenségi vitát. Számukra ez az absztrakciós szint nem nyújt semmit a mindennapi kutatásaikhoz, nem látják ezeknek a vitáknak a gyakorlati hasznát. Hassard és Kelemen (2002) nem sokat foglalkozik ezzel a táborral, holott - ha elfogadjuk Burrell és Morgan (1979) eredeti alapfeltevését, hogy minden kutatónak van valamilyen explicit vagy implicit alapfeltevése a tudományosság kritériumairól és a társadalom kívánatos múködéséról - a „nemfogyasztók” is termelik a tudományos eredményeket, empirikus kutatásokat végeznek, és ezzel hozzájárulnak a szervezetekról való gondolkodásunk befolyásolásához. A,,nemfogyasztók” lehet, hogy nem konzekvensen egy paradigmában dolgoznak, esetleg keverik az alapfeltevéseket, de az is lehet, hogy egy paradigmában kutatnak; keveset lehet tudni róluk.

A második tábor Hassard és Kelemen (2002) szerint az integracionalisták, akik explicit módon arra törekednek, hogy konszenzus alakuljon ki a domináns paradigmáról, mert szerintük a szervezeti kutatások jövőjét kockáztatja ez a preparadigmikusnak túnó állapot, ahol egymás mellett élnek versengő paradigmák. Még identitáskrízist is említenek (Knights, 1997). Pfeffer (1993) a leggyakrabban említett szerzó, aki amellett érvel, hogy a paradigmák ezen fejlettségi szintjén (sic!) roszszabb eséllyel pályáznak a szervezeti kutatók a kutatási és intézményi alapokra, és a tudományok közötti hierarchia alacsony szintjén maradnak a szervezetelméletek. Állítása szerint az egy paradigma melletti összefogás megmenthetné a területet, és fejlődéshez vezetne. Hassard és Kelemen a tudásfogyasztás és -termelés metaforáján keresztül mutatja be, hogy ezt gyakorlatilag lehetetlen véghezvinni, mivel az emberi és politikai tényezót a tudásfogyasztásban maximálisan figyelmen kívül hagyja. Ugyanakkor a kutatói szabadság korlátozása a kreativitást tenné lehetetlenné.

A következô tábor Hassard és Kelemen (2002) szerint a protekcionisták, akik szerint éppen hogy a paradigmák határainak lazítása lenne az akadálya a szervezetelméletek fejlődésének, mivel a paradigmák alapfeltevései egymást kizáróak. Silvermant (1969) idézik, aki szerint nincs nyelvi és analitikus híd a paradigmák között. Jackson és Carter (1991) ebben a táborban úgy fogalmaznak, hogy éppen az összeegyeztethetetlenségnek van emancipatorikus ereje, mert a funkcionalista ortodoxiától védi meg az alternatív gondolatokat. A szintézist teljesen kizárják, és a versengő paradigmák létében látják a garanciát az alternatív paradigmák fenntartásában és minden egyes paradigma önálló identitásának kialakulásában. Ez a tábor védi leginkább Burrell és Morgan (1979) eredeti elképzelését a paradigmák kapcsolatáról.

Pluralistáknak nevezte Hassard és Kelemen (2002) a következő tábort, amelynek követôi el tudnak képzelni valamilyen szintú összeegyeztetést, valamilyen kommunikációt a paradigmák között, és támogatják a multiparadigmikus kutatásokat. A pluralisták megközelítése szerint a különbözô paradigmáknak vannak koncepciói, konstrukciói vagy gyakorlatai, amelyek közösek, és ezekre lehet építeni a kommunikációban. Ugyanakkor nem törekednek szintézisre, összeolvadásra vagy az ellentétek feloldására. A paradigmák közötti dialógust nem csak el tudják képzelni, hanem kívánatosnak tartják. Mivel a multiparadigmatikus megköze- 
lítések tételes áttekintése a célja a tanulmány harmadik részének, itt elegendô arra utalni, hogy eltérô stratégiái (módjai) mellett minden esetben a paradigmák elkülönült egységek maradnak, a saját belsố konzisztens szabályaikat megtartva. Meglepó javaslat, amelyet Hassard és Kelemen (2002) idéz McKinley (1995) és McKinley - Mone (1998) alapján: állítsanak össze egy olyan öszszefoglaló „,szótárt”, amely minden szervezetelmélet területén alkotott (konstruált) fogalmat összegyúijt és definiál. Ez a „szótár” lehetne a kiindulópontja egy olyan közös referenciarendszernek, aminek alapján a paradigmákat összeegyeztetni vagy értékelni lehet. Gyökeresen más megközelítés ahhoz képest, hogy Scherer pedig azt a helyes kritériumot keresi, amely képes értékelni azt, hogy az adott elmélet tudományos-e vagy sem. Kérdés ezen túl az, ha létrejönne, mit kezdenénk az összefoglaló szótárral. Összességében azonban megjegyzendő, hogy a pluralista megközelítés közel áll a protekcionista felfogáshoz, csak a tudományterület fejlódésének (ha úgy tetszik: változásának) garanciáját másban látják.

Végül Hassard és Kelemen (2002) külön táborba sorolta a posztmoderneket. Míg az integracionisták, protekcionisták és pluralisták reflexívek a tudástermelésre, nem mondható ugyanez el a tudás fogyasztásáról. Bár sokan zavarba jönnek a posztmodern irányzatok egymással is összebékíthetetlenül versengó állásfoglalásai miatt, a posztmodern tábor meglepően egységes az újabb és újabb típusú tudás, írásforma, értékek és politikák teremtésében, amellyel a modernista diskurzust szeretnék megkérdôjelezni. A posztmodernisták kétségeiket fejezik ki a paradigmikus gondolkodást eredményező tudástermelés módjával kapcsolatban. Az egész paradigmarendszer, Burrell - Morgan mátrix, a tudományterület fejlődésének kérdése számukra olyan metanarratíva, amellyel szemben a helyi elbeszélések (petit récit) sokkal értékelhetóbbek (Deetz, 1996). A termelés-fogyasztás tekintetében a tudástermelés nagy stratégiája helyett a tudásfogyasztás kis taktikáira koncentrálnának. A korábban csak érintólegesen említett, a Chia (1996) által megfogalmazott lehetséges posztmodern kritika amellett érvel, hogy a szervezeti kutatásokban nagyobb reflexióra lenne szúkség, mert így mozdulna el tudományterületünk posztmodern irányba. A Burrel - Morgan mátrixot ontológiai csalásnak titulálja, mivel a szerzók azt állítják, hogy minden társadalomtudós valamilyen explicit vagy implicit előfeltevéssel rendelkezik a tudományfilozófiában (objektív vagy szubjektív), illetve a társadalomelméletben (rend vagy változás). Ennek alapján egy $2 \times 2$-es mátrixot lehet öszszeállítani, ahova minden kutató besorolható. Ebból következik, hogy ók is besorolhatók valahova. Sót, ha feltételezzük, hogy a paradigmák kölcsönösen kizárják egymást, akkor Burrell és Morgan hol vannak a mátrixban? Ha ók is a mátrix foglyai, akkor hogy tudnak mátrixot létrehozni, hogy tudnak más paradigmákat bemutatni, leírni; pontosan ezt nevezi Chia (1996) ontológiai csalásnak. Ugyanakkor arra is rámutat, hogy Burrell és Morgan (1979) nem az egyetlen szerzópáros, aki magát ilyen privilegizált pozícióba teszi, és a posztmodern éppen ilyen önreflexió hiányára tud rámutatni.

Czarniawska (1998) továbbmegy, az összeegyeztethetetlenségi vitáról szóló különszámban felteszi a kérdést: ki is fél az összeegyeztetéstôl. McKinley és Mone (1998) érveivel egyetértve a másság és hasonlóság egyidejú eszményére építve állítja, hogy létezhet összeegyeztetés, létezhet kommunikáció a paradigmák között, és inkább érdemes félni az olyan egységesító törekvésektól, amelyek a tudományosság kritériumait szeretnék egységesen meghatározni. Czarniawska (1998) érvel a kommunikáció mellett, táborokon belül és táborok között. A fordítások metaforáját hozza be, amelyet ha továbbviszünk, akkor a paradigmavita (és az összeegyeztethetetlenségi vita) érdekes aspektusai világosodhatnak meg. Ha azt tételezzük fel, hogy a paradigmák olyanok, mint a nyelvek, akkor a paradigmák között párbeszéd - fordítás, tolmács, szótár nélkül - lehetetlen. Viszont fordításokkal sok mindent megérthetünk, megismerhetjük egymás kultúráját, rácsodálkozhatunk a saját ki nem mondott alapfeltevéseinkre. Tudjuk mindannyian, hogy idegen nyelvet nem lehet tökéletesen megtanulni, de olyan szinten meg lehet tanulni, hogy képesek legyünk kommunikációra, és minél jobban beszéljük a nyelvet, annál mélyebb kérdéseket vagyunk képesek megvitatni, bár kétségtelen, hogy az anyanyelvünk biztosítja a legmélyebb és legszerteágazóbb kommunikációt. És ha az analógiánál maradunk: vannak kétnyelvú emberek (1. táblázat).

\section{A multiparadigmatikus megközelítés...}

\section{...lehetetlensége}

Amennyiben szó szerinti értelemben fogadjuk el a Burrell - Morgan mátrix paradigmáinak alapfeltevéseit, akkor lehetetlen a multiparadigmatikus megközelítés. Az egyik dimenzió ontológiai, episztemológiai, emberi természetet érintő és metodológiai kérdésekre egymást kizáró választ ad: objektív-szubjektív megközelítés; a másik dimenzió a társadalom természetét tekintve ad egymást kizáró válaszokat: jó-e vagy elvetendő-e a mai kapitalista (fogyasztói) társadalom az ehhez kapcsolódó hatalmi struktúrájával. Egyik kérdésre sem lehet ez is és az is a válasz, ennek a két dimenziónak a végpontjait nem lehet összeegyeztetni. 


\section{A paradigmavita megközelítései}

\begin{tabular}{|c|c|c|}
\hline $\begin{array}{c}\text { Scherer }(1998,1999), \\
\text { Scherer és Steinmann (1999) } \\
\text { alapján }\end{array}$ & $\begin{array}{c}\text { Hassard és Kelemen (2002) } \\
\text { alapján }\end{array}$ & Egyéb \\
\hline & Nem fogyasztók & \\
\hline $\begin{array}{l}\text { Izolacionalisták } \\
\text { Burrell és Morgan (1979) } \\
\text { Jackson és Carter (1991/93) }\end{array}$ & $\begin{array}{l}\text { Protekcionisták } \\
\text { Silverman (1969) } \\
\text { Jackson és Carter (1991/93) } \\
\text { Burrell és Morgan (1979) }\end{array}$ & \\
\hline $\begin{array}{l}\text { Vissza az alapokhoz } \\
\text { Reed (1992) } \\
\text { Donaldson (1998) } \\
\text { Pfeffer (1993) } \\
\text { Schreyög (1992) }\end{array}$ & $\begin{array}{r}\text { Integracionisták } \\
\text { Pfeffer (1993) }\end{array}$ & \\
\hline $\begin{array}{l}\text { Anything goes } \\
\text { Feyerabend (2002) }\end{array}$ & & \\
\hline \multirow[t]{3}{*}{$\begin{array}{l}\text { Multiparadigmatikus } \\
\text { megközelítés } \\
\text { Gioia és Pitré (1990) } \\
\text { Hassard (1991) } \\
\text { Schultz és Hatch (1996) }\end{array}$} & $\begin{array}{l}\text { Pluralisták } \\
\text { McKinley (1995) } \\
\text { és McKinley és Mone } \\
\text { (1998) } \\
\text { Gioia és Pitré (1990) } \\
\text { Hassard (1991) } \\
\text { Schultz és Hatch (1996) }\end{array}$ & \\
\hline & $\begin{array}{r}\text { Posztmodernek } \\
\text { Deetz (1996) }\end{array}$ & $\begin{array}{l}\text { Ontológiai csalók } \\
\text { Chia (1996) }\end{array}$ \\
\hline & & $\begin{array}{l}\text { Fordítások } \\
\quad \text { Czarniawska (1998) }\end{array}$ \\
\hline
\end{tabular}

Forrás: Scherer (1998, 1999), Scherer és Steinmann (1999), Hassard és Kelemen (2002), Chia (1996), Czarniawska (1998)

Hogyan hihetünk egyszerre abban, hogy a világ rajtunk kívül áll (objektivista ontológia) és bennünk létezik (szubjektivista ontológia)? Hogyan hihetünk egyszerre abban, hogy a világ ok-okozati összefüggések hálója (objektivista episztemológia: pozitivizmus), és abban, hogy a világ alapvetően relativista és nem független az azt kutató egyéntốl (szubjektivista episztemológia)? Hogyan hihetünk egyszerre abban, hogy az emberi természet a környezet függvénye (objektivista emberi természet: determinizmus) és abban, hogy az emberi természet alapvetôen aktívan alakítja a világot, autonóm és szabad akaratú (szubjektivista emberi természet: voluntarista)? Hogyan hihetjük egyszerre azt, hogy a vizsgálataink során a társadalmi valóságot megismerhetjük (objektivista metodológia), ahogy az létezik, és azt, hogy csak belépéssel és ott bennszülötté válással részben - szubjektumon keresztül - ismerhetjük meg a társadalmi valóságot (szubjektivista metodológia)? Aki az objektivizmusban
1. táblázat hisz, tipikusan nem hisz a szubjektivizmusban (azt kiküszöbölendő hibának tartja); aki a szubjektivizmusban hisz, elvet minden objektivitásra történó törekvést, amellyel - szerinte - a mindig létező szubjektivizmust eltakarják, vagy nem veszik figyelembe, azaz szükségszerúen tévednek. Míg az objektivista kutató mér, vizsgál, kapcsolatokat keres és talál társadalmi jelenségek között, addig a szubjektivista kutató részt vesz, belehelyezkedik, megért, magyaráz. Az objektivista kutató globális szinten gondolkodik, a szubjektivista kutató lokális szinten. $\mathrm{Az}$ objektivista kutató úgy gondolja, hogy ha jól követi a kutatás szakmai szabályait, akkor nem avatkozik be a kutatás tárgyába, legalábbis nem olyan mértékben, ami befolyásolná az eredményeket, addig a szubjektivista kutató szerint a kutatás beavatkozás, az egyetlen dolog, amit tehet: ezt amennyire csak tudja, explicitté teszi. Ez a két kutatói alapállás, világlátás kizárja egymást.

A másik dimenzió is fundamentálisan eltérô, egymást kizáró választ ad arra a kérdésre, hogy a mai kapitalista társadalom jó-e vagy rossz. A rend szociológiájának hívei alapvetóen elfogadják a kapitalista (fogyasztói) társadalmat: vagy feltétel nélkül éltetik vagy (egyes) hibáit elismerve fogadják el, mert szerintük jobb társadalom - egyelőre - nem létezik. A rend szociológiájának hívei úgy gondolják, hogy minden ezt megelőző társadalom (pl. feudális), vagy egyéb kísérleti társadalom (szocialista, kommunista) kudarcot vallott, és az emberi természetnek leginkább a kapitalista társadalom felel meg. Utópiákban nem hisznek, és ha nem feltétel nélkül fogadják el a kapitalista társadalmat, akkor kisebb vagy nagyobb reformokkal javasolják a társadalmi problémákat orvosolni ( $\mathrm{pl}$. nagyobb állami beavatkozással vagy éppen kisebbel), de alapvetóen 
hisznek a piac szabályozó erejében. Ezzel szemben a radikális változás hívei a kapitalista társadalom alapelveit kérdőjelezik meg, és szerintük fundamentális társadalmi változásokra van szükség ahhoz, hogy emberhez méltó, igazságosabb társadalom jöjjön létre. Szerintük a mai kaptalista társadalom tönkreteszi az embert, és nem is lehet elmenekülni előle. Reformokkal, kis változásokkal nem lehet a társadalmat rendbe tenni. A radikális változás hívei a jelenlegi hatalmi struktúrákat teljesen lebontanák, és igazságosabban újraépítenék. Gondoljunk bele, ezt a két filozófiát nem lehet összeegyeztetni, ebben a kettôben egyszerre nem lehet hinni.

\section{A multiparadigmatikus megközelítés...}

\section{...lehetôsége}

Bármennyire lehetetlen vállalkozásnak túnik, számos kutató próbálkozott multiparadigmatikus kutatással. A két legismertebb ilyen próbálkozás Gioia és Pitré (1990) tanulmánya és Hassard (1991) kutatása. Egészen más alapfeltevésből indulnak ki. Míg Gioia és Pitré (1990) azt feltételezi, hogy a paradigmák határai nem annyira élesek, inkább átjárhatóak, és a határterületen egy átmeneti zóna (transition zone) van, szerintük az itt végzett kutatás lehetne multiparadigmatikus. Hassard (1991) egészen mást tesz, egy kiválasztott szervezetnél (Brit Túzoltóság) négy paradigmában végez kutatást: a funkcionalista paradigmában egy kérdőíves felmérést az ott dolgozók motivációjáról, az interpretatív paradigmában a mindennapi rutinról strukturálatlan interjút és nem részt vevő megfigyelést, amelyhez az etnometodológia módszertani és elméleti alapjait hívja segítségül, a radikális humanista paradigmában olyan tréningeket vizsgált etnografikus módszerrel, amelyek a túzoltók elóléptetéséhez nyújtottak segítséget, végül a radikális strukturalista paradigmában olyan longitudinális vizsgálatot végzett, amely egyes túzoltók szakmai élettörténetét tekintette át. Kétségtelenül más a két multiparadigmatikus kutatás, de az a két ötlet elindította az arról történő vitát, hogy létezhet-e egyáltalán multiparadigmatikus kutatás, és ha igen, azt hogy lehet véghezvinni. Néhány korábbi kutatásról is az állították a multiparadigmikus kutatásban hívôk, hogy már azokat is tekinthetjük az ilyen típusú tanulmányok előfutárainak. A következőkben Lewis és Grimes (1999), valamint Lewis és Kelemen (2002) csoportosításai alapján mutatom be az ilyen kutatásokat és a lehetséges technikákat.

Lewis és Grimes (1999) három nagy csoportra bontja a multiparadigmatikus megközelítést: (1) multiparadigmikus áttekintés (review), (2) multiparadigmatikus kutatások és (3) metaparadigmatikus elméletépítés. Mindegyik csoport többféle multiparadigmatikus technikát alkalmaz, és a felsorolt kutatások közel idôrendben vannak, tehát az újabb és újabb kutatások más-más technikát alkalmaztak. Elôször a multiparadigmatikus áttekintések (review) kerülnek sorra. Két jelentős technika jelent itt meg: a zárójelbe tétel (bracketing) és a hídverés (bridging).

A zárójelbe tétel azt jelenti, hogy a kutatás egy bizonyos szakaszában a többi paradigma alapfeltevéseit zárójelbe tesszük, nem foglalkozunk vele, kvázi elfelejtjük; úgy kutatunk, hogy az éppen alkalmazott paradigmánk alapfeltevéseit tekintjük igaznak, függetlenül attól, hogy egyébként mit is gondolunk a világról. Ezt teszi Morgan (1997, 2006) híres metaforáival például. (Errôl és ennek kritikájáról ld. részletesen Bácsi - Primecz, 2006.) A másik technika az ún. hídverés (bridging), ahol két paradigma közös vonásaira építve (pl. a funkcionalista és interpretatív paradigma esetében a társadalmi rend elfogadása vagy a funkcionalista és radikális humanista esetében az objektív valóság feltételezése) a különbségek között hidat képezünk: megkeressük azokat az elméleteket, amelyek egyszerre feltételezik a kérdéses dimenzió ellentétes végpontjait, és az átmeneti zónában (transition zone) építünk elméletet. Ilyen pl. Giddens strukturációelmélete, amely kiválóan alkalmas a funkcionalista és interpretatív paradigmát összekötni, mert feltételezi, hogy a társadalmi jelenségek az aktorok cselevéseiból jönnek létre (interpretatív: társas konstrukciók), ugyanakkor a meglevő társadalmi jelenségeket adottnak feltételezi (funkcionalizmus: adott objektív valóság).

Gioia és Pitré (1990) az összes átmeneti zónát megvizsgálja és hoz ilyen és ehhez hasonló példákat létező elméletekre. Lewis és Grimes (1999) Gioia és Pitré (1990) közelítését nem tiszta hídverésnek (bridging) tartja, hanem a zárójel betétel és hídverés technikáját egyaránt alkalmazó multiparadigmatikus áttekintésnek. A tiszta hídverés (bridging) példáját többek között Willmottnál (1993) olvashatjuk. Willmott (1993) abból indul ki, hogy az eredeti kuhni paradigmák között világosan kimutatható kapcsolat, pl. az einsteini fizika értelmezhetetlen a newtoni elvek nélkül, azaz az új paradigma meghaladta, ugyanakkor mégis épített rá. Willmott (1993) nem tartja az objektív-szubjektív választást kizárónak, és erre a Labour Process Theory-t (LPT) hozza példaként. Az ortodox LPT a marxista elvekre épít, amelyet Burrell és Morgan (1979) explicit módon a radikális strukturalizmus paradigmájához sorolt, azonban a társadalomtudományokban szubjektivista irányba elmozdulás történt, így a kritikai elméletekben a radikális humanizmus irányban mozdult, de ezek az új elméletek nem értelmezhetóek a marxista 
gyökerek nélkül. Willmott (1993) szerint a két paradigma (radikális strukturalizmus és radikális humanizmus) nem egymást kölcsönösen kizáróak, hanem egymásra építőek, híd van köztük.

Lewis és Grimes (1999) szerint a multiparadigmatikus megközelítés másik nagy csoportja a multiparadigmatikus kutatások, amelyek között megkülönböztet párhuzamos és szekvenciális technikát. A két technika között az a különbség, hogy míg a párhuzamos technikánál kvázi függetlenül folytat a kutató több paradigma szabályai szerint kutatást, és ami egybefogja a kutatást az csak a kutatás tárgya, addig a szekvenciális technikánál a különbözô paradigmákban született eredmények a másik paradigmában történó kutatás kiindulópontjai, az egyik paradigma outputjai a másik paradigma inputjai. Hassard (1991) korábban összefoglalt kutatása a párhuzamos technikát alkalmazza, a négy paradigmában lefolytatott kutatás (kutatási kérdés is) független egymástól, bármelyik kutatást lehetett volna elóbb vagy késóbb végezni. (Hassard [1991] egyébként megjegyzi, hogy jó belépó volt a szervezethez, hogy egy funkcionalista motivációs kérdốívvel kezdte, mert ezáltal a szervezet vezetői elkötelezettekké váltak a kutatásban való részvételben, a funkcionalista kutatás eredményeit hasznosnak találták, így késốbb nem volt gondja a kutatónak a kritikai kutatások lefolytatásában.)

A szekvenciális kutatások olyan szempontból nem tekintik egyenrangúnak a paradigmákat, hogy az egyikben történố eredményeket a másik paradigmában kiindulásnak használják. Pl. egy funkcionalista kérdôív alapja lehet strukturálatlan mélyinterjú-sorozatnak (interpretatív), vagy éppen interjúkkal, megfigyelésekkel (interpretatív) fogalmazódnak meg olyan kérdések, amelyeket késóbb funkcionalista módon kutatnak. Ilyen kutatást mutatott be Lee (1991): etnografikus kutatással feltárt jelentéseket operacionalizálta és tesztelte az általa leírt kutatási példa, így az interpretatív kutatás inputként szolgált a végsố pozitivista kutatás számára. Lewis és Grimes (1999) harmadik csoportja a metaparadigmatikus elméletépítés, ahol nagyon fontos alapvetés, hogy a paradigmák közötti szintézis teljesen kizárt: fontos a hasonlóságok és különbségek ismerete (és fenntartása) a paradigmák között, de az is lényeges, hogy a paradigmák egymáshoz viszonyított kapcsolatát ismerjék a kutatók. Azt a tételt is igaznak tekintik, hogy a paradigmák csak részleges igazságot tárnak fel. Ez a fajta paradigmamegközelítés mindenképpen kitörés a paradigmák fogságából: értelmezhetetlen a paradigmák szintjén, egy paradigmák felett lebegó nézópontot feltételez. Lewis és Grimes (1999) ide sorolja Gioa és Pitré (1990) híres tanulmányát, amelyet korábban a hídverés (bridging) technikánál is említettek. Kétségtelen, hogy a cikk egyik részében a paradigmák felett álló álláspontot támogatják, míg máshol - ahol az átmeneti zónáról (transition zone) beszélnek - paradigmák szintjén, a szürke zónában vannak.

Végül Schultz és Hatch (1996) által megfogalmazott paradigma interplay, amelyet Lewis és Grimes (1999) a metaparadigmatikus elméletépítés másik technikájának ír le. Schultz és Hatch (1996) a saját technikájukat megkülönböztetik a hídveréstól (bridging), a párhuzamos és szekvenciális technikától, ahol szerintük a kutató a paradigmák között oda-vissza mozog, anélkül, hogy integrálná a paradigmákat. Schultz és Hatch (1996) hangsúlyozza a paradigmák közötti feszültséget és az oda-vissza megtermékenyítést, bár nem a paradigmák közötti szürke zónában (átmeneti zóna vagy transition zone) keresi a megoldást, de a hídveró (bridging) technikával egyetért abban, hogy a paradigmahatárok nem olyan merevek és átjárhatatlanok. Bár kevés empirikus kutatás született interplay technikával, a lehetôség adott.

A közelmúltban Romani et al. $(2005,2007)$ mutatta meg, hogy például a Kulturstandard módszernél alkalmazható a paradigma interplay (2. táblázat).

2. táblázat

A multiparadigmatikus megközelítés csoportjai

\begin{tabular}{|c|c|c|}
\hline Multiparadigmatikus áttekintés (review) & $\begin{array}{c}\text { Multiparadigmatikus } \\
\text { kutatás }\end{array}$ & $\begin{array}{c}\text { Metaparadigmatikus } \\
\text { elméletépítés }\end{array}$ \\
\hline Zárójel betétel (bracketing) & Párhuzamos \\
Pl. Morgan (1997) & Pl. Hassard (1991) & $\begin{array}{c}\text { Metaelmélet-építés } \\
\text { Pl. Gioia és Pitré (1990) }\end{array}$ \\
\hline Zárójel betétel (bracketing) & Szekvenciális \\
és hídverés (bridging) Pl. Gioia és Pitré (1990) & Pl. Lee (1991) & $\begin{array}{c}\text { Interplay } \\
\text { Pl. Schultz és Hatch (1996) }\end{array}$ \\
\hline Hídverés (bridging) & & \\
Pl. Willmott (1993) & & \\
\hline
\end{tabular}

Forrás: Grimes és Lewis (1999) alapján saját összeállítás 


\section{Konklúzió}

Tudományterületünk, a szervezetelméletek, meglehetôsen fragmentált terület, számtalan elmélet él és virágzik egymás mellett látszólag függetlenül. Azonban vannak elméletek, amelyek közelebb állnak egymáshoz, míg mások távolabb. Ha alaposan megvizsgáljuk az egymáshoz közeli és távoli elméleteket, észrevehetjük, hogy alapfeltevések szintjén lehet hasonlóságot és különbséget felfedezni köztük. Ha a sokféleség rendetlenség érzetét kelti bennünk, akkor segít a Burrell - Morgan (1979) mátrix eligazodni, amiból ugyan a posztmodern kimaradt, de hát milyen rendszerbe is férne bele a posztmodern? Ha megértjük és elfogadjuk a Burrell - Morgan (1979) mátrixot, akkor azt is megértjük, hogy ez a tudományterület nem a szintézist, az integrációt támogatja. Mégis, mintha minden paradigmában lenne valami, ami miatt nehéz teljesen elvetni azt. A multiparadigmatikus megközelítéshez úgy lehet eljutni, hogy az ember eljut odáig, hogy a paradigmákat nem lehet összeegyeztetni. Az összeegyeztethetetlensé-gi tézis nélkül a multiparadigmatikus megközelítés értelmezhetetlen. Ez a csoda szúrôdik át a bevezetốben említett FSCO különböző zenei hatásokból építkező muzsikájából.

\section{Lábjegyzet}

${ }^{1}$ Mind az angol, mind a magyar nyelvú forrásokban kétféle leírással olvasható a fogalom: interpretív (interpretive) és interpretatív (interpretative). Lsd. Gelei (2002), Pataki (2003), Topçu (2005) magyarul, angolul pedig Burrell - Morgan (1979), Burrell (1996), Morgan (1980, 1990), Hassard (1991) többek között. Burrell és Morgan (1979) eredeti múvét idézve maradok az interpretív formánál, egyébként pedig a magyar nyelven elterjedtebb interpretatív verziónál.

${ }^{2}$ Magam azt feltételeztem a PhD-kutatásom idején, hogy olyan multiparadigmikus kutatást végzek, amely három paradigmára (1) pozitivizmusra (funkcionalizmus), (2) kritikai realizmusra és (3) - egy dupla csavarral - posztmodernizmusra épül (Primecz, 2000). Ma már nem feltétlenül tartanám posztmodernnek ezt a kutatást.

\section{Felhasznált irodalom}

Bácsi - Primecz (2006): Scratching Morgan’s Sandcastle. Challenging Morgan's View on Connection between Paradigms and Metaphors, EGOS Colloquium, Bergen

Bokor (1994): Posztmodern a menedzsmenttudományban, Közgazdasági Szemle, 16/12.

Burrell, G. (1996): Normal Science, Paradigms, Metaphors,

Discourses and Genealogies of Analysis, in: Handbook of Organization Studies, eds.: Clegg, S.R., Hardy, C., Nord, W.R., Sage Publications, London

Burrell - Morgan (1979): Sociological Paradigms and Organisational Analisys, Heinemann, London
Chia (1996): The Problem of Reflexivity in Organizational Research: Towards a Postmodern Science of Organization, Organization, 3(1)

Chia (2003): Organization as a Postmodern Science, in: Oxford Handbook of Organization Thory, eds. Tsoukas and Knudsen, Oxford University Press, Oxford

Czarniawska (1998): Who Is Afraid of Incommensurability?, Organization, 5(2)

Deetz (1996): Describing Differences in Approaches to Organization Science: Rethinking Burrell and Morgan and Their Legacy, Organization Science, 7(2)

Donaldson (1998): The Myth of Paradigm Incommensurability in Management Studies: Comments by an Integrationist, Organization, 5(2)

Donaldson (2005?): Organization Theory as Positive Science, in: Oxford Handbook of Organization Thory, eds. Tsoukas and Knudsen, Oxford University Press, Oxford

Feyerabend (2002): A módszer ellen, Atlantisz, Budapest

Gelei (2002): A szervezeti tanulás interpretatív megközelítése: a szervezetfejlesztés esete, PhD.disszertáció

Gelei (2006): A szervezet interpretatív megközelítése, Vezetéstudomány, különszám

Gioia - Pitré (1990): Multiparadigm Perspectives on Theory Building, Academy of Management Review, 15/4

Hassard (1991): Multiple Paradigms and Organizational Analysis: A Case Study, Organization Studies, 12/2

Hassard - Kelemen (2002): Production and Consuption in Organizational Knowledge: The Case of the 'Paradigm Debate', Organization, 9(2)

Hatch (1997): Organization Theory. Modern, Symbolic, and Postmodern Perspectives, Oxford University Press

Hatch - Cunliffe (2006): Organization Theory. Modern, Symbolic, and Postmodern Perspectives, Second edition, Oxford University Press

Hatch - Yanow (2003): Organization Thoery as an Interpretive Science, in: Oxford Handbook of Organization Thory, eds. Tsoukas and Knudsen, Oxford University Press, Oxford

Jackson - Carter (1991): In Defence of Paradigm Incommensurability, Organization Studies, 12/1

Jackson - Carter (1993): 'Paradigm Wars': A Response to Hugh Willmott, Organization Studies, 14/5

Knights (1997): Organization Theory in the Age of Deconstruction: Dualism, Gender and postmodernism Revised. Organization Studies, 18/1

Kuhn (2002): A tudományos forradalmak szerkezete, Osiris Könyvtár, Budapest

Lee (1991): Integrating positivist and interpretivist approaches to organizatonal research, Organizational Science, 2: 342-365

Levie (1993): Paradigmák a vezetéstudományban, Vezetéstudomány, 1-2. sz.

Lewis - Grimes (1999): Metatriangulation: Building Theory from Multiple Paradigms, Academy of Management Review, 24/4 
Lewis - Kelemen (2002): Multiparadigm inquiry: Exploring organizational pluralism and paradox, Human Relations, $55(2)$

Lyotard (1993): A posztmodern állapot, in.: A posztmodern állapot, szerk.: Bujalos István, Századvég Kiadó, Budapest

McKinley - Mone (1998): The Re-construction of Organization Studies: Wrestling with Incommensurability, Organization 5(2)

Morgan, G. (1980): Paradigms, Metaphors, and Puzzle Solving in Organization Theory, in: Critical Perspectives on Organization and Management, eds. Smircich, L., Calás, M. B., Dartmounth Publishing Limited, Hants

Morgan, G. (1990): Paradigm diversity in organizational research, in: The theory and philosophy of organizations (edited by J. Hassard, D Pym) pp. 13-29

Morgan (1996): Images of Organization, 2nd ed., Sage Publications, London

Morgan (2006): Images of Organization, 3rd ed, Sage Publications, London

Organization (1998) összeegyeztethetetlenségi különszám

Pataki (2003): Az ökológiailag fenntartható vállalat, PhDdisszertáció

Pfeffer (1993): Barriers to the Advance of Organizational Science: Paradigm Development as a Dependent Variable, Academy of Management Review, 18(4)

Primecz (1999): A szervezeti tudás születése. A szervezetelméletek pozitivista, kritikai realista és posztmodern közelítése, Vezetéstudomány, XXX. évf. 6. sz.

Primecz (2000): Multi-Paradigm Perspectives on CrossCultural Management, PhD-disszertáció

Reed (1992): The Sociology of Organizations: Themes, Perspectives and Prospects, New York, Harvester Weatsheaf

Roman - Topcu - Primecz (2005): The Kulturstandard method: Venue for Paradigm Interplay in Cross-Cultural Management, EGOS Colloquium, Berlin

Romani - Primecz - Topсu (2007): Moving forward with Multiple Paradigms: Paradigm Interplay in Cross-Cultural Management with Kulturstandard method, Academy of Management Annual Meeting, Philadelphia, Division Research Method
Scherer (1998): Pluralism and Incommensurability in Strategic Management and Organization Theory: A Problem in Search of Solution, 5(2)

Scherer (1999): Kritik der Organisation oder Organisation der Kritik? Wissenschaftstheoretische Bemerkungen zum kritischen Umgang mit Organisationstheorien, in.: Organisationstheorien, 3., überarbeitete und erweiterte Auflage, Hrsg. In: Kieser (2002): Szervezetkritika vagy szervezett kritika? - Tudományelméleti megjegyzések a szervezetelméletek kritikus alkalmazásához, kézirat, 2002. fordította: Lazányi Kornélia és Tirnitz Tamás

Scherer - Steinmann (1999): Some Remarks on Problem of Incommensurability in Organization Studies, Organization Studies, 20/3

Schreyög (1992): Book review of John Hassard and Denis Pym (eds.): The theory and Phylosophy of Organizations. Critical Issues and New Prespectives, Organization Studies: 13: p. 121-125

Schultz - Hatch (1996): Living with Multiple Paradigms: The Case of Paradigm Interplay in Organization Culture Studies, Academy of Management Review, 1(2)

Silverman (1969): Correspondence: Organization: A Rejoinder, Sociology, 3(3): p. 420-421.

Toárniczky - Primecz (2006): Multicultural Diversity Through OrganizationalCultureLences:AMultiparadigmApproachThe Fondazione Eni Enrico Mattei Series Index. http://www.feem. it/Feem/Pub/Publications/EURODIVPapers/default.htm

Tорси (2005): A kulturstandard-kutatás elmélete és gyakorlata magyar-osztrák menedzser-interakcióban: egy magyar szempontú jellemzés, PhD-disszertáció

Tsoukas - Knudsen (ed.) (2003): Oxford Handbook of Organization Thory, Oxford University Press, Oxford

Willmott (1993): Breaking the Paradigm Mentality, Organization Studies, 14/5

Willmott (2003): Organization Theory as Critical Science, Forms of Analysis and ,New Organizational' Forms, in: Oxford Handbook of Organization Thory, eds. Tsoukas and Knudsen, Oxford University Press, Oxford

Cikk beérkezett: 2007. 9. hó

Lektori vélemény alapján átdolgozva: 2008. 2. hó

\section{E SZÁMUNK SZERZÖI}

Dr. Barakonyi Károly, DSc, egyetemi tanár, Pécsi Tudományegyetem; Dr. Bakacsi Gyula, CSc, egyetemi docens, Budapesti Corvinus Egyetem; Dr. Balaton Károly, DSc, egyetemi tanár, Budapesti Corvinus Egyetem; Dr. Dobák Miklós, CSc, egyetemi tanár, Budapesti Corvinus Egyetem; Dr. Erdôsi Gyula, CSc, ügyvezető igazgató, Pontus Kft.; Dr. Szintay István, CSc, egyetemi tanár, Miskolci Egyetem; Dr. Primecz Henriett, PhD egyetemi docens, Budapesti Corvinus Egyetem; Dr. habil. Noszkay Erzsébet, egyetemi docens, Szent István Egyetem, Gödöllő, a VOE (Változás- és Válságmenedzserek Országos Egyesülete) elnöke; Badinszky Péter, PhD-hallgató, Szent István Egyetem; Dr. Kulcsár László, egyetemi tanár, kandidátus, Szent István Egyetem; Dr. Hoffer Ilona, egyetemi docens, Budapesti Corvinus Egyetem; Dr. Iványi Attila Szilárd, egyetemi tanár, Budapesti Corvinus Egyetem; Dr. Fojtik János, egyetemi docens, Pécsi Tudományegyetem; Rubóczky István, nyugd. oszt. vez. 